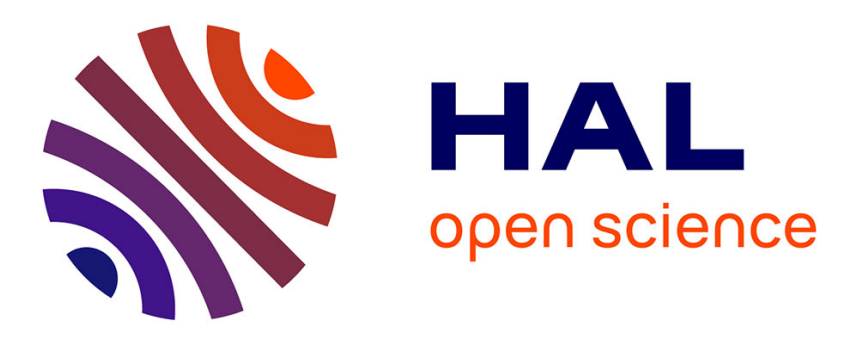

\title{
Differences of floral resource use between honey bees and wild bees in an intensive farming system
}

Orianne Rollin, Vincent Bretagnolle, Axel Decourtye, Jean Aptel, Nadia Michel, Bernard E. Vaissiere, Mickaël Henry

\section{- To cite this version:}

Orianne Rollin, Vincent Bretagnolle, Axel Decourtye, Jean Aptel, Nadia Michel, et al.. Differences of floral resource use between honey bees and wild bees in an intensive farming system. Agriculture, Ecosystems and Environment, 2013, 179, pp.78-86. 10.1016/j.agee.2013.07.007 . hal-00919063

\section{HAL Id: hal-00919063 https://hal.science/hal-00919063}

Submitted on 29 May 2020

HAL is a multi-disciplinary open access archive for the deposit and dissemination of scientific research documents, whether they are published or not. The documents may come from teaching and research institutions in France or abroad, or from public or private research centers.
L'archive ouverte pluridisciplinaire HAL, est destinée au dépôt et à la diffusion de documents scientifiques de niveau recherche, publiés ou non, émanant des établissements d'enseignement et de recherche français ou étrangers, des laboratoires publics ou privés. 


\title{
Differences of floral resource use between honey bees and wild bees in an intensive farming system
}

\author{
Orianne Rollin ${ }^{\mathrm{a}, \mathrm{b}, *}$, Vincent Bretagnolle $^{\mathrm{d}}$, Axel Decourtye ${ }^{\mathrm{a}, \mathrm{b}}$, Jean Aptel ${ }^{\mathrm{c}}$, Nadia Michel ${ }^{\mathrm{e}}$, \\ Bernard E. Vaissière $^{b, c}$, Mickaël Henry ${ }^{b, c}$ \\ a ACTA, Site Agroparc, F-84914 Avignon, France \\ b UMT Protection des Abeilles dans l'Environnement, CS 40506, F-84914 Avignon, France \\ c INRA, UR 406 Abeilles et Environnement, CS 40509, F-84914 Avignon, France \\ d Centre d'Etudes Biologiques de Chizé, CNRS, UPR 1934, F-79360 Beauvoir-sur-Niort, France \\ e Université de Lorraine - INRA, UMR 1121 Laboratoire Agronomie et Environnement, F-54505 Vandœuvre-lès-Nancy, France
}

Keywords:

Apoidea

Mass-flowering crop

Semi-natural habitat

Agri-environmental schemes

Agrosystem

Generalized linear mixed model

\begin{abstract}
A B S T R A C T
Bees provide an essential pollination service for crops and wild plants. However, substantial declines in bee populations and diversity have been observed in Europe and North America for the past 50 years, partly due to the loss of natural habitats and reduction of plant diversity resulting from agricultural intensification. To mitigate the negative effects of agricultural intensification, agri-environmental schemes (AES) have been proposed to sustain bees and others pollinators in agrosystems. AES include the preservation of semi-natural habitats such as grasslands, fallows, woodlots, hedgerows or set-aside field margins. However, empirical evidence suggest that the use of those semi-natural habitats by bees may vary greatly among bee functional groups and may further be influenced by the presence of alternative foraging habitats such as mass-flowering crops. The present study sets out to investigate whether the three bee groups typically targeted by AES (honey bees, bumble bees and other wild bees) differ in the way they use those semi-natural habitats relative to common mass-flowering crops (oilseed rape, sunflower, alfalfa) in an intensive agricultural farming system. A clear segregation pattern in the use of floral resources appeared between honey bees and wild bees, with the former being tightly associated with mass-flowering crops and the latter with semi-natural habitats. Bumble bees had an intermediate strategy and behaved as habitat generalists. Therefore, it would be sensible to treat the three bee groups with distinct AES management strategies, and to further consider potential effects on AES efficiency of alternative foraging habitats in the surrounding. This study also stresses the importance of native floral resources, particularly in semi-natural herbaceous habitats, for sustaining wild bee populations.
\end{abstract}

\section{Introduction}

Flower-visiting animals provide substantial pollination services for a wide range of wild plants and crops worldwide (Klein et al., 2007; Ollerton et al., 2011). The economic value of insect-mediated pollination for agriculture at the global scale was estimated to be $€ 153$ billion in 2005, considering only the crops that are used by humans for food (Gallai et al., 2009). Bees (Hymenoptera, Apoidea) are a keystone group in this pollination process. However, the last 50 years have witnessed a global decline in both honey bees and wild bees in European and North American agricultural landscapes

* Corresponding author at: INRA, UR 406 Abeilles et Environnement, CS 40509, F-84914 Avignon, France. Tel.: +33 0432722621.

E-mail addresses: orianne.rollin@avignon.inra.fr, orianne.rollin@gmail.com (O. Rollin)
(Biesmeijer et al., 2006; VanEngelsdorp et al., 2008; Potts et al., 2010; Cameron et al., 2011), with potential concern about the pollination of both entomophilous flowering crops and wild plant species. This global decline of pollinators and many other taxa in farming landscapes has been linked to agricultural intensification, usually associated with a substantial reduction of the quality and quantity of grasslands and semi-natural habitats (Benton et al., 2003; Duelli and Obrist, 2003; Tscharntke et al., 2005).

In order to promote bees and other pollinators in agrosystems and to mitigate the negative effects of agricultural intensification, agri-environmental schemes (AES) have been proposed (Dicks et al., 2010), targeting either honey bees (Apis mellifera), bumble bees (Bombus spp.) or other wild bees. Agri-environmental schemes dedicated to pollinators can be split into two broad categories, later referred to as resource-oriented schemes and habitat-oriented schemes (Dicks et al., 2010). The resource-oriented approach consists in increasing the amount of specific floral resources at 
Version définitive du manuscrit publiée dans / Final version of the manuscript published in :

Agriculture, Ecosystems and Environment (2013), Vol. 179, p. 78-86, DOI: 10.1016/j.agee.2013.07.007

\section{Journal homepage: www.elsevier.com/locate/agee}

the local scale by sowing attractive flower covers like scorpion weed Phacelia tanacetifolia (Decourtye et al., 2010), clover Trifolium spp., alfalfa Medicago sativa or mustard Sinapsis spp. (Dicks et al., 2010). However the chosen "pollen and nectar mixes" are usually foraged by a limited subset of bee species, due to morphological or phenological incompatibilities (Kirk and Howes, 2012). Alternatively, the habitat-oriented approach consists in protecting and restoring (semi-) natural habitats with the aim to promote wild floral resources co-evolved with native bees. Natural and semi-natural habitats are fields or landscape areas with reduced management, including grasslands, fallows, woodlots, hedgerows or set-aside field margins (Gathmann et al., 1994; Steffan-Dewenter and Tscharntke, 2001; Ricketts et al., 2008).

However, both theoretical and empirical evidence suggest that the use of those semi-natural habitats in intensive farming systems may vary greatly among bee functional groups and also depending on the presence of attractive mass-flowering crops. Mass-flowering crops may be intensively used by bees in agrosystems and are liable to influence the way bees use other habitats in the environment (Holzschuh et al., 2011; Tscharntke et al., 2012). For instance, flowered field margins tend to be less used by honey bees when alternative floral resources increase in the vicinity (Henry et al., 2012). Furthermore, all bee groups may not be influenced in the same way by the presence of mass flowering crops in the environment. Honey bees may show a strong preference for mass-flowering crops because they need to store large amounts of food to sustain colony development, and have evolved social and behavioural adaptations to optimize foraging efficiency in that respect (Dyer, 2002; Dornhaus and Chittka, 2004). In particular, mass-flowering crops can be the major pollen suppliers for honey bees throughout the year in an intensive farming system ( $62 \%$ of the year-round pollen harvest, compared to $32 \%$ and $4.5 \%$ for trees and grasslands plants, respectively; (Odoux et al., 2012). Conversely, wild bees need to provision each cell in their nest with enough food for one larva to complete its growth (Michener, 2007), and therefore might perform well with less abundant but more diversified native floral resources. Bumble bees, which are eusocial species but with annual and much smaller colonies than honey bees, might display an intermediate resource use pattern.

To test these predictions, we compared five different foraging habitats among the three broad bee groups targeted by AES. Studied foraging habitats were either semi-natural areas or mass flowering crops. Within the former, we distinguished semi-natural herbaceous habitats (grasslands and road and field margins) and semi-natural woody habitats (hedgerows and forest edges). Massflowering crops include oilseed rape Brassica napus, sunflower Helianthus annuus and alfalfa Medicago sativa. These crops offer big-bang floral resources, i.e. locally very abundant monofloral resources of short duration (Herrmann et al., 2007; Westphal et al., 2009). The use of those different foraging habitats by bees was assessed by means of flower-visit surveys in order to test whether the three bee groups differed in the way they used mass-flowering crops vs. semi-natural habitats. The implication of those results for the landscape scale planning of agri-environmental schemes will also be discussed.

\section{Materials and methods}

This study was carried out in the springs and summers of 2010, 2011 and 2012 in the Zone Atelier Plaine et Val de Sèvre, a $500 \mathrm{~km}^{2}$ intensive agricultural area managed as a long-term ecological research (LTER) site by the Centre d'Etudes Biologiques de Chizé (CEBC-CNRS) within the Poitou-Charentes Region in Western France. The study site comprises over 16,000 fields, mostly used for cereal production. During 2010-2012, annual crops accounted on average for $80 \%$ of total land cover ( $40 \%$ for cereals, $9 \%$ for oilseed rape, $12 \%$ for sunflower and $9 \%$ for maize). Forest patches and permanent grassland covered only $3 \%$ and $7 \%$ of the total land of the study area, respectively. The information on land use is updated twice a year since 1995, for every single field, and stored into a geographic information system (ArcGIS, ESRI).

Due to phenological differences between floral resources present in the different habitat types (Odoux et al., 2012), it was not possible to perform all pairwise comparisons of resource use. Instead, surveys were grouped by crop flowering period. During oilseed rape full flowering, in April-May, other available foraging habitats considered for comparison were semi-natural herbaceous and woody habitats. During sunflower full flowering, in July-August, other available foraging habitats for comparison with sunflower, were flowering alfalfa and semi-natural herbaceous habitats. Flowering woody species were too scarce for meaningful comparisons during the latter period (see Section 3).

\subsection{Sampling design}

The relative use of foraging habitats by the different bee groups was investigated using surveys of flower-visiting bees. In order to cover a wide variety of ecological contexts across the whole study area, we favoured an extensive sampling strategy, which consisted of short bee surveys in many sites. Over the three years, a total of 812 sites were surveyed, located in 30 grid cells (10 cells/year) randomly drawn without replacement from a $3.3 \times 3.3 \mathrm{~km}$ spacing grid covering the whole study area (Appendix A). The grid cell size (about $10 \mathrm{~km}^{2}$ ) was set to encompass the approximate foraging range of honey bee colonies (Steffan-Dewenter and Kuhn, 2003).

Sampled habitats were either (i) a mass-flowering crop field (oilseed rape, sunflower or alfalfa), (ii) a flowering tree, or a patch of flowering shrubs or epiphytic plants in semi-natural woody habitats (hedgerows, forest edges or stand-alone trees), or (iii) a conspicuous patch of spontaneous wild flowers in semi-natural herbaceous habitats (permanent grasslands, external field margins, spontaneous weed plants in crops).

Sites were surveyed once each by capturing flower-visiting bees along walking transects (crops and herbaceous habitats) or at observation plots (woody habitats) during 15 min sampling sessions. At flowering trees, shrubs or epiphyte observation plots, field workers captured bees on accessible flowers. Walking transects were $50 \mathrm{~m}$ long and $2 \mathrm{~m}$ wide. The $50 \mathrm{~m}$ length was estimated to be the distance required to cover the whole floral species richness in patches of herbaceous wild flowers typically sampled in our study area.

Transects in flowering crops were established from the median part of the most accessible field margin and towards the field centre. A buffer distance of $10 \mathrm{~m}$ from the field margin was used to reduce edge effect. Bees were captured with a net, exclusively when foraging on a flower. The visited flowers were identified in situ to the finest taxonomical level possible, or collected for subsequent identification in the laboratory. Whenever necessary, ladders and insect nets mounted on a $2 \mathrm{~m}$ long perch were used to permit captures in higher vegetation strata.

Unlike flowering crops and grasslands, whose location were exhaustively recorded prior to each sampling period, the occurrence of wild flower patches could not be determined a priori, which precluded purely random sampling site selection. Instead, we favoured a pseudo-random sampling strategy whereby wild flower patches were chosen along predetermined prospection itineraries in a way that reproduced a random-like selection. Within each grid cell, we had randomly selected a transversal itinerary along trails and secondary road networks prior to each sampling session. In a first step, all mass-flowering crops and grasslands (with wild flowers patches) located within a $500 \mathrm{~m}$ array 
Version définitive du manuscrit publiée dans / Final version of the manuscript published in :

\section{Agriculture, Ecosystems and Environment (2013), Vol. 179, p. 78-86, DQI: 10.1.016/j.agee.2013.07.007 Journal homepage: www.elsevier.com/locate/agee}

from the chosen itinerary were systematically visited and sampled. While travelling among those fields, all accessible wild flower patches were sampled in semi-natural habitats other than grasslands (e.g. field margins, hedgerows), respecting a minimal $50 \mathrm{~m}$ distance among samples. In a second step, field workers further sampled as many additional flowering crops and wild flowers patches in grasslands and other semi-natural habitats as possible within the grid cell. Exhaustiveness was often reached within a grid cell for the least common field types (alfalfa and grasslands).

Wild herbaceous flower patches (e.g. in grasslands or field margins) were not sampled if the flower cover was too scarce, or if they were shorter than the $50 \mathrm{~m}$ length requirement. As an exception to this $50 \mathrm{~m}$ rule, two smaller contiguous flower patches were occasionally assimilated to a single one, provided that they were located $<10 \mathrm{~m}$ apart.

Overall, this strategy led to the survey of a large number of flowering crops and wild flower patches, located at various ranges of distances from each other, and with a preserved homogeneity between habitat types in terms of spatial and temporal distribution. The 10 grid cells to be investigated during a given year and crop period could be processed within about 12-15 days.

Sites were sampled between 10:00 and 19:00, and only under good weather, that is with temperatures ranging from $16^{\circ} \mathrm{C}$ to $35^{\circ} \mathrm{C}$ and wind speed less than $15 \mathrm{~km} / \mathrm{h}$ (see also Hoehn et al., 2010; Westphal et al., 2008). Temperature and wind speed were systematically checked prior to each site sampling. Bees were sampled during full bloom periods of oilseed rape and sunflower. Oilseed rape sampling periods were from April 16th to May 1st in 2010, from April 1st to 13th in 2011, and from April 6th to May 5th in 2012. Sunflower sampling periods were from July 16 th to 23rd in 2010, from June 28th to July 12 th in 2011 , and from July 17 th to August 7th in 2012.

\subsection{Characterization of resource use by bees}

Foraging bees were classified into three groups, namely honey bees, bumble bees and all other wild bees. This classification matches the usual broad AES target bee groups (Dicks et al., 2010), and is further justified by major differences in their biological traits and status. One bumble bee species, Bombus terrestris, is reared as well, but these colonies are used mainly for the pollination of greenhouse crops (Velthuis and Doorn, 2006), which are absent or uncommon in the study area. Non-managed bees were also split into bumble bees, usually of greater body size and eusocial, and other wild bees.

Resource use was defined as the relative foraging intensity recorded for each bee group (honey bees, bumble bees, wild bees) in the different floral habitat types, as revealed by the number of foraging bees found in sampling sites. Bee counts in sampling sites were zero-inflated, i.e. displayed much more null values than expected from a usual frequency distribution (e.g. Poisson distribution). This indicates that additional mechanisms may further limit the use of resource patches by bees. To avoid possible biases, bee occurrence frequency, i.e. presence-absence data at sampling sites, were first computed and analysed. In a second step, bee abundance (counted bees per $50 \mathrm{~m}$ transect or $15 \mathrm{~min}$ observation plot) among habitat types was compared on presence-only sampling sites.

\subsection{Data analysis}

Analyses consisted of comparing among habitat types and bee groups the bee occurrence frequency and bee abundance. Therefore, in the subsequent analyses, generalized linear modelling approaches were used with occurrence ( 0 - 1 binary data) and abundance (counts) as dependent variables, while habitat type, bee group, and their two-way interaction, were the main explanatory variables. A binomial error distribution family was specified in occurrence models, and a Poisson family, which is well suited for count data, in abundance models.

Direct abundance comparisons between transect data (crops and herbaceous wild habitats) and observation plot data (woody habitats) were not fully informative due to the methodological differences. However, what is at issue here is whether habitat use differed among bee groups, which statistically would result as a significant interaction between habitat type and bee group, regardless of habitat-specific sampling method.

Prior to the statistical comparison of resource use descriptors among habitat types and bee groups, possible confounding factors or other sources of significant statistical noise were investigated in our dataset. The possible biases were (i) spatial autocorrelation at small scales, (ii) distribution gradients at the study area scale (i.e. non-stationarity), (iii) inter-annual variations and (iv) temperature-dependent variations in bee foraging activity at the daily scale.

Auto-correlation in honey bee foraging activity may occur over a range of about $80-400 \mathrm{~m}$ (Henry et al., 2012). To assess whether our dataset was subject to autocorrelative biases, we proceeded in three steps. First, we sought possible spatial dependence among residuals of null models, i.e. simple statistical models with no explanatory variable specified. Generalized linear models (GLMs) where performed separately by habitat type and by bee group to figure out where in the dataset autocorrelation might occur. Second, the autocorrelation analysis was repeated a posteriori on the residuals of the final models used for hypothesis testing (see below). This was to check whether the autocorrelation potentially detected at the first step persisted in the analysis or was removed by our model parameterization. Third, would the assumption of independence of residuals still be unsatisfied, an additional spatial grouping variable was introduced in models to fix the non-independency among neighbouring samples. To do so, within each grid cell, sampling sites were clustered based on Euclidian distances. Clusters of neighbouring sites were determined by cutting the cluster tree at the level of the autocorrelation upper distance range. The cluster identity was introduced as an additional random grouping level in the mixed model structure described thereafter. In all cases, autocorrelation was analysed using spline correlograms on model residuals (Rhodes et al., 2009). Spline correlogram uncertainty was assessed by Monte Carlo simulations (Bjornstad and Falck, 2001) with 1000 simulated random data sets, using the $n f c$ package (Bjornstad, 2009) in R version 2.12.0 (R Development Core Team, 2010).

Possible bias due to large-scale distribution gradient was systematically accounted for by including the grid cell identity as a random factor within the frame of a mixed model structure, i.e. generalized linear mixed models (GLMMs). Likewise, interannual variations were accounted for by including the year as a higher-level random variable, within which grid cells were nested. Finally, temperature-dependant variations could be accounted for by introducing temperature $\left({ }^{\circ} \mathrm{C}\right)$ as a fixed variable in the models. Bee foraging activity is affected by temperature (Corbet et al., 1993; Kelber et al., 2006; Kwon and Saeed, 2003), but its effect on bee occurrence frequency or bee abundance might not be linear. To model a quadratic shape, raw and squared temperature data where implemented jointly, after raw data were standardized to avoid collinearity (Saveliev et al., 2009). An interaction term between standardized temperature and bee group was also specified because all bee groups are not equally affected by temperature (Corbet et al., 1993).

Complete models included six fixed effect variables, namely habitat type (oilseed rape, semi-natural herbaceous habitat and semi-natural woody habitat during oilseed rape flowering; sunflower, semi-natural herbaceous habitat and alfalfa field during 
Version définitive du manuscrit publiée dans / Final version of the manuscript published in :

Agriculture, Ecosystems and Environment (2013), Vol. 179, p. 78-86, DOI: 10.1016/j.agee.2013.07.007

\section{Journal homepage: www.elsevier.com/locate/agee}

sunflower flowering), bee group (honey bees, bumble bees, wild bees), interaction between habitat type and bee group, standardized and squared temperature for quadratic modelling, and interaction between standardized temperature and bee group. Parameter estimates were based on the restricted maximum likelihood estimation (REML) method because this method reduces the biases of maximum likelihood estimates (Zuur et al., 2009). For the sake of statistical parsimony, complete models were simplified into minimum adequate models (MAMs) by sequentially dropping nonsignificant terms following model comparisons based on likelihood ratio tests. Interactions were assessed first. If they were significant, their individual terms were also kept in the model.

Whenever an interaction between habitat type and bee group was kept in the MAM, the model was repeated on subsets of the initial dataset to test a posteriori all pairwise interactions among habitat types and bee groups. The $p$-values were adjusted accordingly using the sequential Bonferroni correction for multiple tests (Holm's sequential Bonferroni).

Analyses were performed separately for the two mass flowering periods, i.e. oilseed rape and sunflower. Therefore, four models were produced, one for each resource use descriptor (bee occurrence and abundance) and for each mass flowering period (oilseed rape and sunflower). GLMMs were computed using the lme4 package (Bates et al., 2011) in R version 2.12.0 ( $R$ Development Core Team, 2010).

\subsection{Implications for agri-environmental schemes}

To investigate the possible implications of our results for AES planning, occurrence and abundance model predictions were combined to assess how effective - in terms of resource use - would be the conversion of a given land surface into a habitat-oriented AES, compared to a mass-flowering crop. To do so, we evaluated pairwise scenario where bees were offered landscape elements (e.g. field margins) converted into semi-natural herbaceous habitats on the one hand, and equal amounts of unconverted mass-flowering crop surfaces on the other hand. The relative AES effectiveness was measured as:

$E=\frac{n_{s n h}-n_{m f c}}{n_{s n h}+n_{m f c}}$

where $n_{\text {snh }}$ and $n_{m f c}$ are the total number of bees predicted to forage at one particular moment in the semi-natural herbaceous landscape units and in the mass-flowering landscape units, respectively. Effectiveness $E$ varies from - 1 (all bees in the mass-flowering crop, minimum AES efficiency) to 1 (all bees in the semi-natural herbaceous habitat, maximal AES efficiency), and tends towards 0 when the two habitats attract equal numbers of foraging bees. Eq. (2) gives an estimate of $n_{s n h}$ :

$n_{\text {snh }}=S \times P \times f_{\text {snh }} \times a_{\text {snh }}$

where $S$ is the total surface converted into semi-natural herbaceous habitat, $P$ is the percentage surface $S$ occupied by patches of wild floral resources, and $f_{s n h}$ and $a_{s n h}$ are the MAM predictions for the bee occurrence frequency and abundance in flower patches. $P$ was set to vary from $1 \%$ to $30 \%$. Likewise, $n_{m f c}$ was calculated following Eq. (2), whilst $P$ was by definition set to $100 \%$. Herein, $S$ is arbitrary and can be removed from equations whenever scenarios are based on equal surfaces between semi-natural and cropped habitats. Simulations were calculated using bee occurrence frequency and abundance model predictions at minimal and maximal temperatures.

\section{Results}

A total of 29,720 foraging bees were recorded ( 21,852 honey bees, 1356 bumble bees and 6512 wild bees; Table 1 ) in the 812 sampling sites. Most of the honey bees were found during the sunflower period. Wild bees belonged to 6 families and 22 genera. Samples covered a total of 127 flowering plant species, of which 74 were effectively visited by bees.

Little evidence of autocorrelative bias was found in either occurrence and abundance datasets. Exceptions were the abundance of honey bees in both oilseed rape and sunflower fields, with a positive autocorrelation detected over $2 \mathrm{~km}$, and both the occurrence and abundance of bumble bees in sunflower over $3 \mathrm{~km}$. The spatial dependency of residuals was removed at the MAM stage (see below), indicating that it was unlikely to affect our analysis. Bumble bee abundance in sunflower still displayed a minor autocorrelation at short distance $(<1600 \mathrm{~m})$ in the MAM residuals. This was fixed by further grouping neighbouring samples located $<1600 \mathrm{~m}$ apart from each other into an additional nesting level within the GLMM random effects.

Few model simplifications were allowed to alleviate complete models. In occurrence models, the interaction between temperature and bee group was not significant, both for oilseed rape and sunflower periods (Table 2), and was therefore removed to compute the occurrence MAMs. All other variables had a significant effect or were involved in significant interactions. In abundance models, all variables had a highly significant effect. Therefore complete models were regarded as the abundance MAMs.

Temperature appeared to be an important correlate of the occurrence and abundance of bees during both the oilseed rape and sunflower periods (Table 2). Its overall effect was negative, with fewer bees foraging at high temperatures.

\subsection{Relative use of flowering crops and semi-natural habitats by bees}

Significant differences in resource use were observed for each bee group. The most striking illustration of these differences in resource use is provided during the sunflower period. Honey bees occurred in all of the 177 sampled sunflower fields at an average abundance $>40$ times greater than that of wild bees (Fig. $1 \mathrm{~B}$ and D). Conversely, wild bees were found 2.5 times more often than honey bees in semi-natural herbaceous habitats and their abundance was also 2.5 times greater than honey bees. The pattern was not so clear-cut between oilseed rape and woody habitats for honey bees because they were found equally often in these two habitats. No significant difference in the occurrence and abundance of wild bees was found between flowering alfalfa fields relative to semi-natural herbaceous resources. Finally, in agreement with our expectations, bumble bees had an intermediate strategy: like honey bees, they were found significantly less frequently in semi-natural herbaceous habitats compared to other habitats (Fig. 1A and B). However, like wild bees, presence-only data revealed that bumble bees were found in significantly greater abundance in semi-natural habitats than in oilseed rape or sunflower (Fig. 1C and D). The complete pairwise comparison results among habitat types are provided in Appendix B.

The interaction effects between habitat type and bee group merely reveals how the different bee groups differ in the way they use foraging habitats (Fig. 2). The complete pairwise interaction results between bee groups and habitat types are provided in the Appendix $C$. The most marked and consistent differences in resource use were observed between honey bees, whose occurrence and abundance were strongly biased towards flowering crops compared to all other habitats, and wild bees, whose occurrence and abundance where strongly biased towards semi-natural habitats. Indeed, oilseed rape and sunflower were significantly more used by honey bees than by bumble bees and wild bees, whereas wild bees preferred semi-natural habitats over oilseed rape and sunflower.

The high attractiveness of flowering alfalfa compared to semi-natural herbaceous habitats for the three bee groups was marked. All bee groups were found more frequently in flowering alfalfa fields than in semi-natural herbaceous habitats, and there was no significant difference among honey bees, bumble bees and wild bees regarding their occurrence frequency in alfalfa (Fig. 2B). However, honey bees were more abundant in alfalfa than in semi-natural herbaceous habitats, compared to bumble bees and wild bees (Fig. 2D). There was little or no difference between the three bee groups in the use of semi-natural woody habitats compared to seminatural herbaceous habitats (Fig. 2A and C). However, the difference in abundance of bumble bees between the two types of semi-natural habitat was less than that observed for honey bees and wild bees (Fig. 2C). This propensity of bumble bees to use resources in a balanced way was conformed to our initial predictions of intermediate foraging strategy.

\subsection{Implications for agri-environmental schemes}

The AES efficiency simulations preserved the overall clear-cut segregation pattern between honey bees and wild bees in terms of resource use, as well as the rather intermediate strategy displayed by bumble bees (Fig. 3). Temperature had an overall limited effect on predicted AES efficiency, though more marked on wild bees. In all pairwise scenarii (AES semi-natural herbaceous habitat on one hand vs. oilseed rape, sunflower or alfalfa on the other hand), the semi-natural habitats were overall expected to attract much fewer honey bees, regardless the percentage surface occupied by wild flower patches. Conversely, semi-natural herbaceous habitats would clearly favour wild bees over bumble bees. However, during the oilseed rape period, a wild flower cover threshold appeared (ca. 4-8\% of total herbaceous surface) below which a semi-natural herbaceous habitat would hold less foraging wild bees than an equivalent oilseed rape surface (Fig. 3A). Such a threshold was not detected during the sunflower period due to the fairly low sunflower attractiveness 
Version définitive du manuscrit publiée dans / Final version of the manuscript published in :

Agriculture, Ecosystems and Environment (2013), Vol. 179, p. 78-86, DQI: 10.1.016/j.agee.2013.07.007

Journal homepage: www.elsevier.com/locate/agee

Table 1

Total number of recorded bees, and sampling sites.

\begin{tabular}{|c|c|c|c|}
\hline Sampling period & & Oilseed rape period & Sunflower period \\
\hline \multirow[t]{3}{*}{ Number of observed bees } & Honey bees & 1950 & 19,902 \\
\hline & Bumble bees & 298 & 1058 \\
\hline & Wild bees & 3016 & 3496 \\
\hline \multirow[t]{5}{*}{ Number of sampled sites } & Oilseed rape & 143 & - \\
\hline & Sunflower & - & 177 \\
\hline & Herbaceous semi-natural & 252 & 183 \\
\hline & Woody semi-natural & 21 & - \\
\hline & Alfalfa & - & 36 \\
\hline
\end{tabular}

for wild bees compared to semi-natural herbaceous habitats (Fig. 3B). Alfalfa, on the contrary, performed better for all bee groups compared to semi-natural herbaceous habitats during this period (Fig. $3 \mathrm{C}$ ), regardless the percentage surface occupied by native flower patches.

\section{Discussion}

Overall, strong evidence of differential habitat use among the three bee groups was found both during oilseed rape and sunflower flowering periods. Honey bees tended to be more frequently observed and more abundant in mass-flowering crops (oilseed rape and sunflower) than in semi-natural habitats, which conformed to our initial predictions. This observation is also congruent with the biannual honey flow from oilseed rape in spring and sunflower in summer, as reported by professional beekeepers in the region, confirming that honey bees make an intensive use of those mass flowering crops.

Conversely, wild bees used more frequently and in greater abundance the native floral resources in semi-natural habitats, particularly woody habitats in spring, and herbaceous habitats in summer. Wild bees were also much rarer than honey bees in massflowering crops. The differential pattern of habitat use between wild bees and honey bees appeared particularly contrasted during the sunflower period, with wild bee occurrence frequency and abundance values being nearly 50 times lower than those of honey bees in sunflower fields, against three or four times lower only in oilseed rape fields. Wild bees may preferentially forage in seminatural habitats because those habitats harbour more diversified food resources combined with more nesting opportunities (Potts et al., 2003; Steffan-Dewenter and Tscharntke, 2001).
However, wild bee abundance in herbaceous semi-natural resource patches was highly variable. A single $50 \mathrm{~m}$ transect may return capture numbers ranging from 0 to 95 and from 0 to 225 wild bees during oilseed rape and sunflower periods, respectively No wild bee was found in nearly one-third (32\%) of all semi-natural herbaceous samples. This heterogeneity in wild bee abundances may be largely accounted for by the floral diversity and species composition in sampling sites. Flower species do not attract equally the different wild bee species. Some bee species, also referred to as monolectic or oligolectic, have a very narrow dietary spectrum, while polylectic species have a generalist foraging behaviour (Michener, 2007). Dietary preferences are partly driven by morphological characteristics or other life history traits (Kirk and Howes, 2012; Michener, 2007). For instance, long-tongued bees (such as the families Megachilidae and Apidae) can forage flowers with both deep and short corollas, whereas short-tongued bees (such as the families Halictidae and Andrenidae) can only forage flowers with short corolla, like flowers of Asteraceae family.

Bumble bees displayed an intermediate pattern of habitat use. Like honey bees, they occurred less frequently in semi-natural herbaceous habitats compared to mass-flowering crops (oilseed rape, sunflower, alfalfa) and semi-natural woody habitats. But unlike honey bees, they were found at their lowest abundance levels in oilseed rape and sunflower. They had a rather ubiquitous, but low-abundance, distribution pattern, which somehow contrasted with that of honey bees and wild bees. Different processes could explain this intermediate pattern. First, most bumble bees are medium or long-tongued species. They can forage from a wide variety of flowers, with deep or short corolla. However, long-tongued Bombus species are more efficient on flowers with deep corollas than on flowers with short corollas (Ranta and

Table 2

Factors associated with the occurrence frequency and abundance of bee groups, based on GLMMs and log-likelihood ratio tests. The “ $\times$ ” denote statistical interactions.

\begin{tabular}{|c|c|c|c|c|c|}
\hline Model & Variables & LogLik & $\chi^{2}$ & df & $p$ \\
\hline \multirow[t]{5}{*}{ Occurrence frequency during oilseed rape period } & Bee group & -759.45 & 53.608 & 2 & $<0.001$ \\
\hline & Type of habitat & -759.45 & 89.487 & 2 & $<0.001$ \\
\hline & Temperature (quadratic function) & -759.45 & 21.738 & 2 & $<0.001$ \\
\hline & Bee group $\times$ type of habitat & -651.08 & 214.66 & 4 & $<0.001$ \\
\hline & Temperature $\times$ bee group & -651.08 & 1.382 & 2 & 0.501 \\
\hline \multirow[t]{5}{*}{ Occurrence frequency during sunflower period } & Bee group & -781.5 & 4.6814 & 2 & 0.096 \\
\hline & Type of habitat & -781.5 & 13.212 & 2 & 0.002 \\
\hline & Temperature (quadratic function) & -781.5 & 7.4206 & 2 & 0.024 \\
\hline & Bee group $\times$ type of habitat & -572.21 & 416.29 & 4 & $<0.001$ \\
\hline & Temperature $\times$ bee group & -572.21 & 2.0117 & 2 & 0.366 \\
\hline \multirow[t]{5}{*}{ Abundance during oilseed rape period } & Bee group & -4821.1 & 2622.2 & 2 & $<0.001$ \\
\hline & Type of habitat & -4821.1 & 1214.7 & 2 & $<0.001$ \\
\hline & Temperature (quadratic function) & -4821.1 & 59.023 & 2 & $<0.001$ \\
\hline & Bee group $\times$ type of habitat & -3340.5 & 2942.3 & 4 & $<0.001$ \\
\hline & Temperature $\times$ bee group & -3340.5 & 11.769 & 2 & 0.003 \\
\hline \multirow[t]{5}{*}{ Abundance during sunflower period } & Bee group & $-12,979$ & 25,287 & 2 & $<0.001$ \\
\hline & Type of habitat & $-12,979$ & 6333.4 & 2 & $<0.001$ \\
\hline & Temperature (quadratic function) & $-12,979$ & 121.98 & 2 & $<0.001$ \\
\hline & Bee group $\times$ type of habitat & -5099.2 & 15,745 & 4 & $<0.001$ \\
\hline & Temperature $\times$ bee group & -5099.2 & 174.02 & 2 & $<0.001$ \\
\hline
\end{tabular}


Version définitive du manuscrit publiée dans / Final version of the manuscript published in :

Agriculture, Ecosystems and Environment (2013), Vol. 179, p. 78-86, DOI: 10.101.6/j.agee.2013.07.007

Journal homepage: www.elsevier.com/locate/agee

Oilseed rape flowering

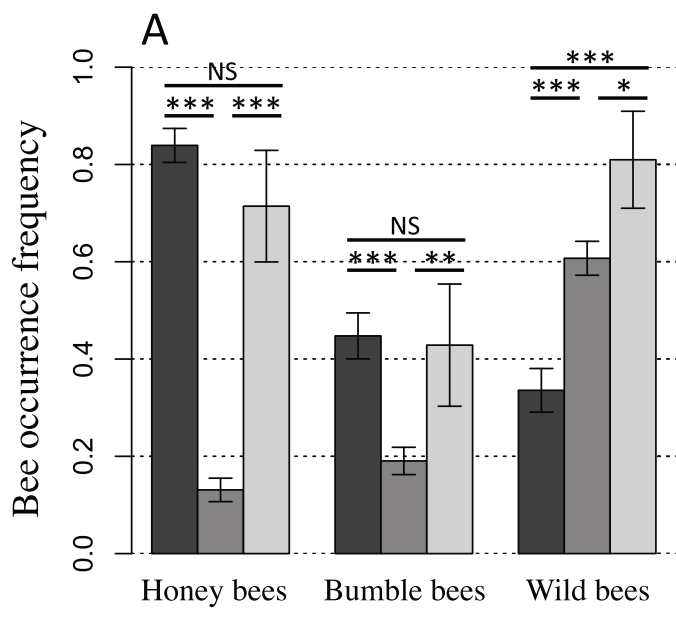

C

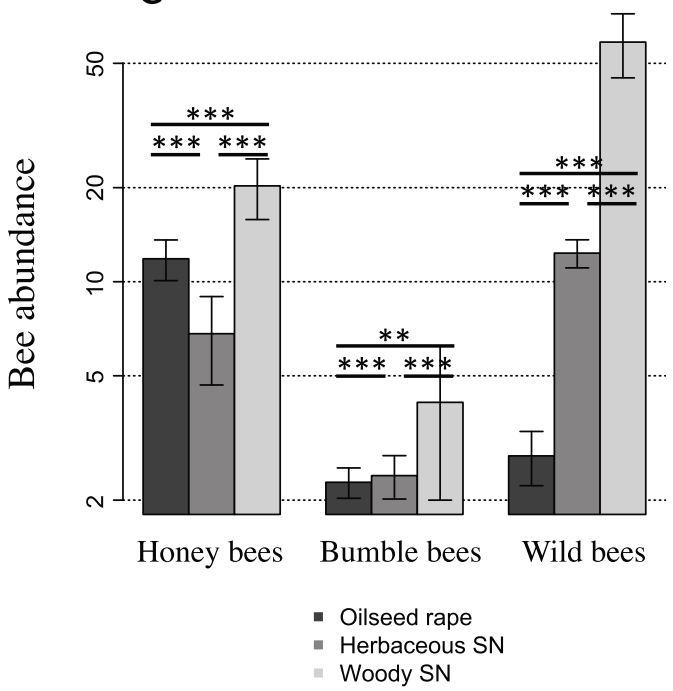

Sunflower flowering
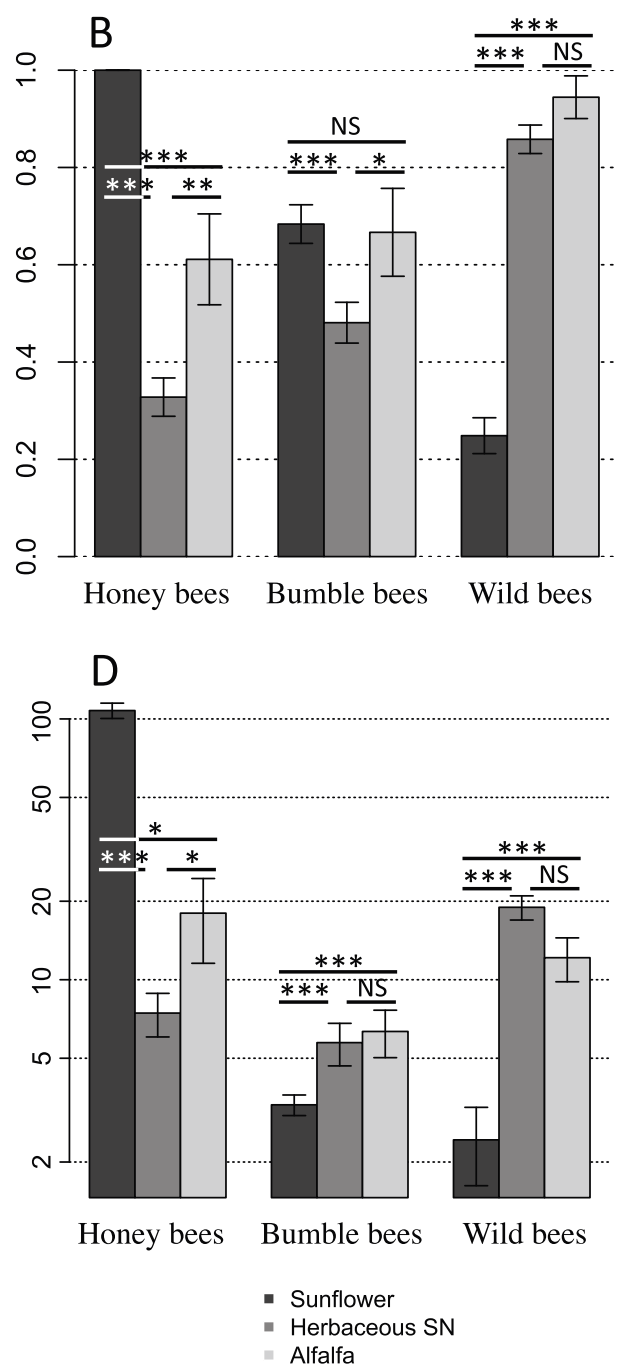

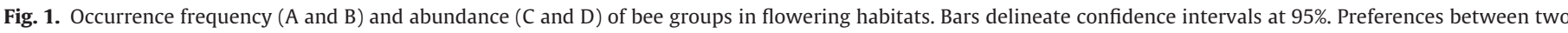

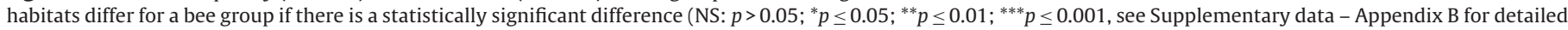
statistics).

Lundberg, 1980). Thus, oilseed rape and sunflower, both displaying short corollas, might not be viewed as optimal resources compared to e.g. alfalfa deep flowers. Second, sociality and foraging behaviour can largely determine resource use. Honey bees are eusocial and need to store large amounts of food to sustain the development of their large colonies year-round. To do so, they have evolved social and behavioural adaptations to optimize foraging efficiency (the waggle dance to communicate food resource location; Dyer, 2002; Dornhaus and Chittka, 2004). Bumble bees, on the other hand, form much smaller, annual colonies (Michener, 2007) and do not provision food for winter as the queen alone will overwinter.

Beside the above-described patterns of ecological segregation, one might suspect that ecological complementary effects occur among habitats. Habitat complementarity means that organisms need two or more habitats in their range to maintain sustainable populations (Dunning et al., 1992). In our study area, honey bees occurred as often in semi-natural woody habitats as in oilseed rape sampling sites and at rather high abundances, indicating that they use both resources in a possibly non-substitutable way. This is further supported by palynological data from our study region (Odoux et al., 2012) showing that apart from mass-flowering crops, trees are the greatest providers of pollen for honey bees, while pollen from grassland accounts for a marginal part of total harvest. Likewise, possible complementary habitat use might occur (i) between oilseed rape and woody floral resources during the first study period for bumble bees, (ii) between sunflower and alfalfa during the second study period for bumble bees and (iii) between alfalfa fields and semi-natural herbaceous habitats during the second study period for wild bees. However, the habitat complementary hypothesis remains to be documented with deeper details on pollen vs. nectar use, inter-habitat distance effects and species-specific estimates of fitness.

The differential habitat use by the three bee groups might result in high variability in AES effectiveness, as has been observed for a wide range of taxa (Kleijn and Sutherland, 2003; Kleijn et al., 2001; Knop et al., 2006). Therefore, it appears sensible to treat the three bee groups with distinct AES management strategies, and to take into account possible mutual influences among foraging habitats. In an attempt to do so, a series of general recommendations regarding different AES management options is proposed below.

Resource-oriented AES through the promotion of mass-flowering crops. Alfalfa was the most evenly used flowering crop among 
Version définitive du manuscrit publiée dans / Final version of the manuscript published in :

Agriculture, Ecosystems and Environment (2013), Vol. 179, p. 78-86, DOI: 10.1.016/j.agee.2013.07.007

Journal homepage: www.elsevier.com/locate/agee

Pairwise habitat difference in bee occurrence frequency

A

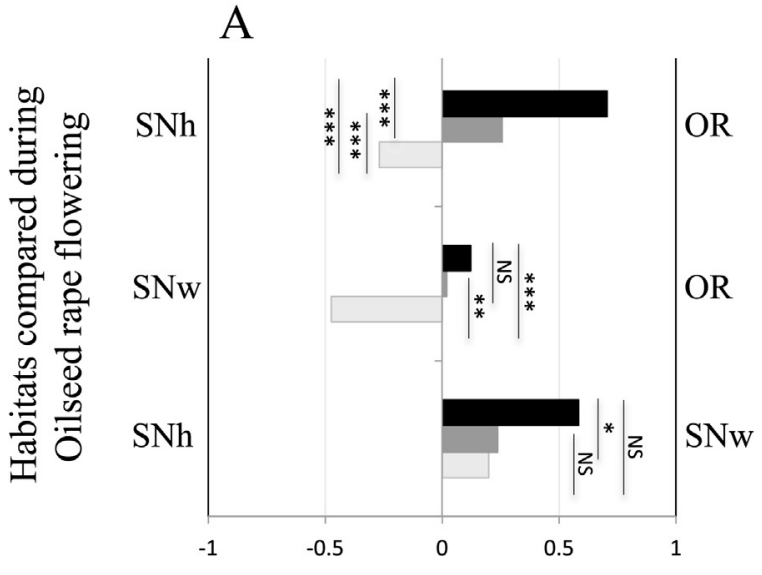

B

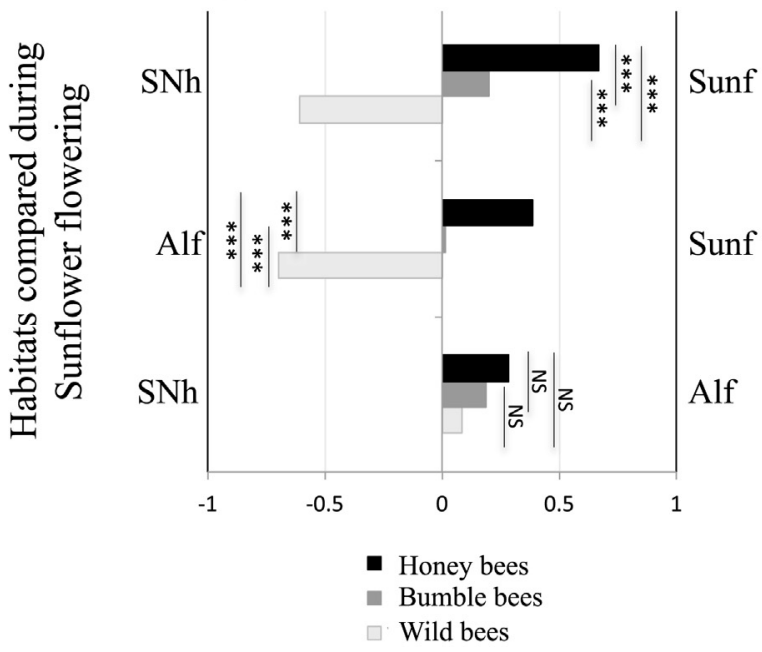

Pairwise habitat difference in bee abundance

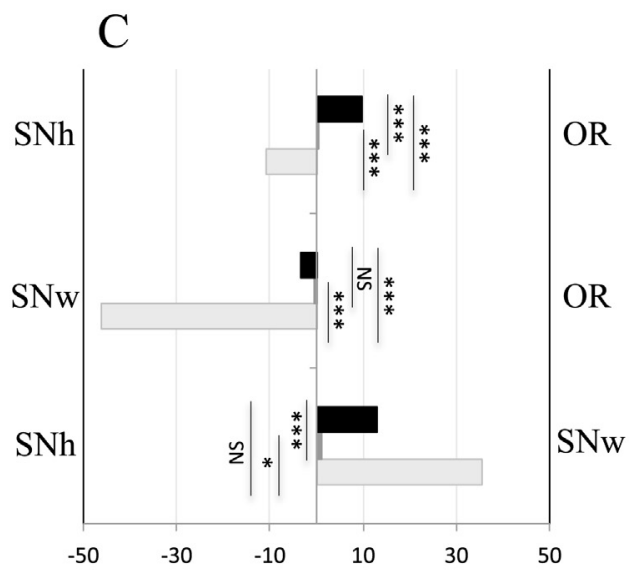

$\mathrm{D}$

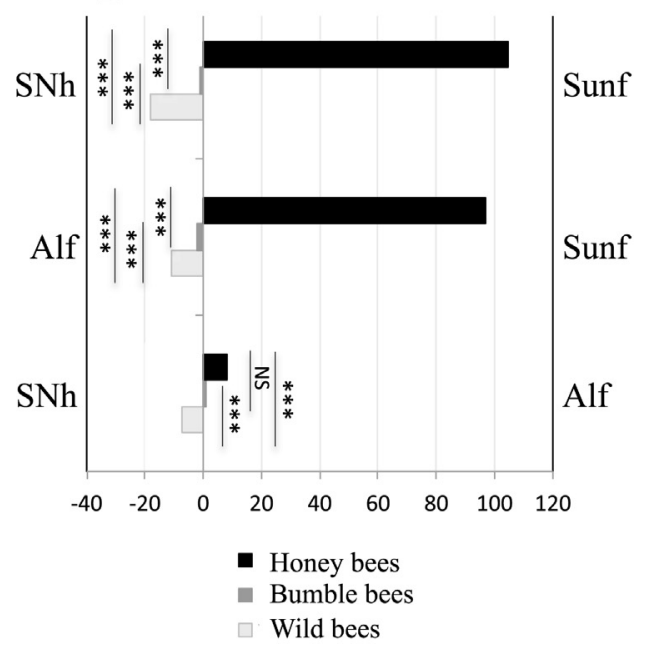

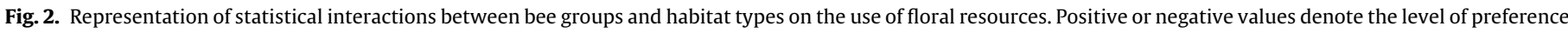

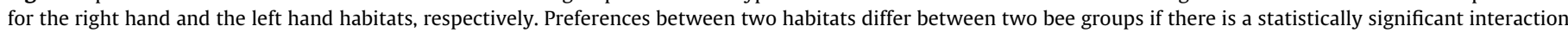

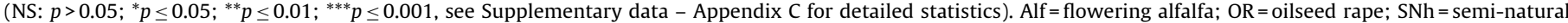
herbaceous habitats; SNw = semi-natural woody habitats; Sunf = sunflower.

the three bee groups, considering both occurrence frequency and abundance. However, floral morphology of alfalfa flowers is probably not well suited for all bee species. Only $30 \%$ of all wild bee genera reported in this study were observed in alfalfa (Andrena, Halictus, Hoplosmia, Lasioglossum, Megachile, Melitta, Xylocopa). Moreover, honey bees were much more abundant in flowering alfalfa, in August-September, i.e. after the sunflower crop (personal observations, OR). In that respect, alfalfa-oriented AES should be combined with the restoration of semi-natural habitats. Beside alfalfa, promoting the mass-flowering oilseed rape and sunflower will disproportionately benefit honey bees, and to a lesser extent bumble bees. However, given the pervasiveness of those two massflowering crops in modern farming systems ( $9 \%$ and $12 \%$ of total land cover, respectively, in our study area), it is unlikely that further increasing their quantity in the environment will make a substantial difference in terms of population fitness. On the contrary, some studies have questioned the effect of excessive oilseed rape cover on bumble bee foraging activity. Diekötter et al. (2010) found that high amounts of oilseed rape in the landscape can have a negative effect on interactions between wild plants and bumble bees. Similarly, Holzschuh et al. (2011) have shown that wild plant pollination by bumble bees decreases with increasing oilseed rape proportion in the landscape. Seed set of Primula veris, whose blooming overlaps with that of oilseed rape, was reduced by $20 \%$ when the amount of oilseed rape within $1 \mathrm{~km}$ radius raised from $0 \%$ to $15 \%$.

Promoting semi-natural woody habitats. Actions intended to favour the recovery of woody vegetation like hedgerows or forest edges, especially including trees from the Rosaceae family, such as Prunus spp., Malus spp., Crataegus spp., will benefit both honey bees and wild bees. Most importantly, honey bees will rely on the pollen of those trees (Odoux et al., 2012) complementarily with the rather nectar-dominated use of oilseed rape in spring. At this period of the year, brood production rapidly expands in the hives, and the income of pollen protein is critical to support that process.

Promoting semi-natural herbaceous habitats. Habitat-oriented AES dedicated to promote natural herbaceous regeneration in grasslands, field margins or fallows will be the most effective way to favour wild bees in general. However, depending on the context, there might be a minimum flower cover threshold needed for herbaceous habitat-oriented AES to be more profitable to wild bees than resource-oriented AES. There might be an optimum that returns the best compromise among the different wild bee families.

Current AES practices in the study area include especially two types of AES contracts on alfalfa crops, designed to promote 
Version définitive du manuscrit publiée dans / Final version of the manuscript published in :

Agriculture, Ecosystems and Environment (2013), Vol. 179, p. 78-86, DOI: 10.101.6/j.agee.2013.07.007

\section{Journal homepage: www.elsevier.com/locate/agee}

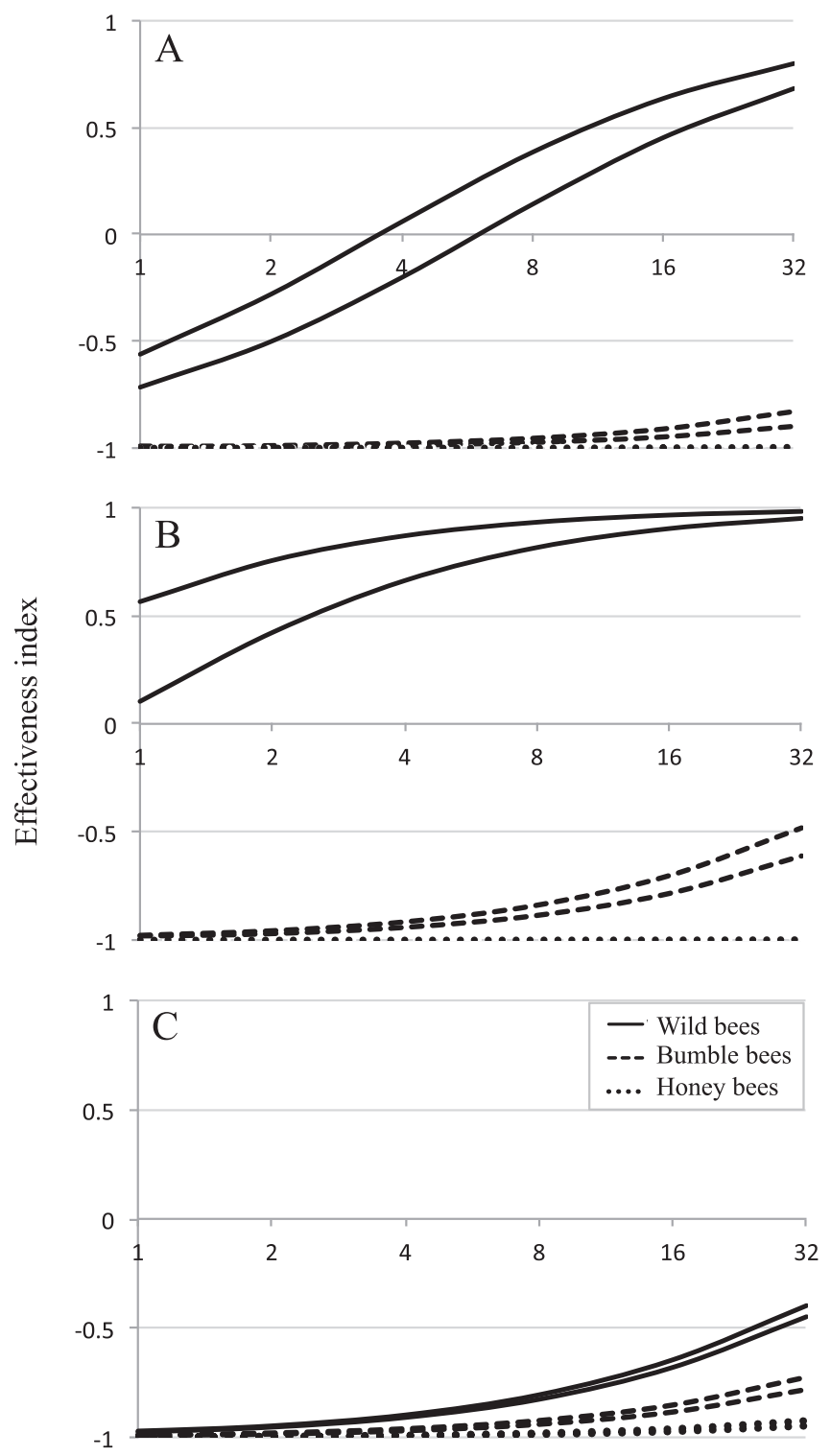

Percentage of herbaceous semi-natural habitat with patches of wild floral resources

Fig. 3. Effectiveness simulations of habitat-oriented AES relatively to (A) oilseed rape, (B) sunflower, or (C) alfalfa for each bee group, considering field-realistic proportions of semi-natural herbaceous habitats occupied by patches of wild floral resources, at minimal and maximal sampling temperatures (upper and lower lines, respectively).

little bustard populations, a bird species red-listed in France. The first type involves the conversion of annual crops into perennial grassland and fodder crops (mainly alfalfa) for 5 years to increase the extent of perennial crops; the second type prevents the mowing of alfalfa in June, which may be used by females little bustard during the incubation period (Bretagnolle et al., 2011). This mass-flowering crop can provide alternative floral resources in the landscape during and after the sunflower flowering period. Moreover, this crop was the most evenly used flowering crop by wild bees during sunflower flowering and by all bee groups after the sunflower period. As such, it presents advantages as a candidate resource-oriented environmental scheme for bees, in addition to be a habitat-oriented agri-environmental scheme for birds.

\section{Acknowledgements}

We would like to thank C. Maffre and A. Haefflinger for field assistance and L. Guilbaud for bee identification to genus level. J.F. Odoux, M. Chabirand and C. Toulet provided valuable help and suggestions on the field. We also thank the farmers of the study sites for allowing us to perform surveys on their fields. We are grateful to the editor and an anonymous reviewer for their constructive corrections. This work was funded by the French Ministry of Agriculture (CASDAR programme no. 9035) and an ANRT CIFRE Ph.D. grant allocated to OR.

\section{Appendix A. Supplementary data}

Supplementary data associated with this article can be found, in the online version, at http://dx.doi.org/10.1016/j.agee.2013.07.007.

\section{References}

Bates, D., Maechler, M., Bolker, B., 2011. Ime4: linear mixed-effects models using S4 classes.

Benton, T.G., Vickery, J.A., Wilson, J.D., 2003. Farmland biodiversity: is habitat heterogeneity the key? Trends in Ecology \& Evolution 18, 182-188.

Biesmeijer, J.C., Roberts, S.P.M., Reemer, M., Ohlemuller, R., Edwards, M., Peeters, T., Schaffers, A.P., Potts, S.G., Kleukers, R., Thomas, C.D., Settele, J., Kunin, W.E., 2006. Parallel declines in pollinators and insect-pollinated plants in Britain and the Netherlands. Science 313, 351-354.

Bjornstad, O.N., 2009. ncf: spatial nonparametric covariance functions.

Bjornstad, O.N., Falck, W., 2001. Nonparametric spatial covariance functions: estimation and testing. Environmental and Ecological Statistics 8, 53-70.

Bretagnolle, V., Villers, A., Denonfoux, L., Cornulier, T., Inchausti, P., Badenhausser, I., 2011. Rapid recovery of a depleted population of Little Bustards Tetrax tetrax following provision of alfalfa through an agri-environment scheme. Ibis 153, 4-13.

Cameron, S.A., Lozier, J.D., Strange, J.P., Koch, J.B., Cordes, N., Solter, L.F., Griswold, T.L., 2011. Patterns of widespread decline in North American bumble bees. Proceedings of the National Academy of Sciences 108, 662-667.

Corbet, S.A., Fussell, M., Ake, R., Fraser, A., Gunson, C., Savage, A., Smith, K., 1993. Temperature and the pollinating activity of social bees. Ecological Entomology $18,17-30$

Decourtye, A., Mader, E., Desneux, N., 2010. Landscape enhancement of floral resources for honey bees in agro-ecosystems. Apidologie 41, 264-277.

Dicks, L.V., Showler, D.A., Sutherland, W.J., 2010. Bee Conservation: Evidence for the Effects of Interventions, Synopses of Conservation Evidence. Pelagic Publishing.

Diekötter, T., Kadoya, T., Peter, F., Wolters, V., Jauker, F., 2010. Oilseed rape crops distort plant-pollinator interactions. Journal of Applied Ecology 47, 209-214.

Dornhaus, A., Chittka, L., 2004. Why do honey bees dance? Behavioral Ecology and Sociobiology 55, 395-401.

Duelli, P., Obrist, M.K., 2003. Regional biodiversity in an agricultural landscape: the contribution of seminatural habitat islands. Basic and Applied Ecology 4, $129-138$.

Dunning, J.B., Danielson, B.J., Pulliam, H.R., 1992. Ecological processes that affect populations in complex landscapes. Oikos 65, 169-175.

Dyer, F.C., 2002. The biology of the dance language. Annual Review of Entomology 47, 917-949.

Gallai, N., Salles, J.-M., Settele, J., Vaissière, B.E., 2009. Economic valuation of the vulnerability of world agriculture confronted with pollinator decline. Ecological Economics 68, 810-821.

Gathmann, A., Greiler, H.-J., Tscharntke, T., 1994. Trap-nesting bees and wasps colonizing set-aside fields: succession and body size, management by cutting and sowing. Oecologia 98, 8-14.

Henry, M., Fröchen, M., Maillet-Mezeray, J., Breyne, E., Allier, F., Odoux, J.-F., Decourtye, A., 2012. Spatial autocorrelation in honeybee foraging activity reveals optimal focus scale for predicting agro-environmental scheme efficiency. Ecological Modelling 225, 103-114.

Herrmann, F., Westphal, C., Moritz, R.F.A., Steffan-Dewenter, I., 2007. Genetic diversity and mass resources promote colony size and forager densities of a social bee (Bombus pascuorum) in agricultural landscapes. Molecular Ecology 16, 1167-1178.

Hoehn, P., Steffan-Dewenter, I., Tscharntke, T., 2010. Relative contribution of agroforestry, rainforest and openland to local and regional bee diversity. Biodiversity and Conservation 19, 2189-2200.

Holzschuh, A., Dormann, C.F., Tscharntke, T., Steffan-Dewenter, I., 2011. Expansion of mass-flowering crops leads to transient pollinator dilution and reduced wild plant pollination. Proceedings of the Royal Society B 278, 3444-3451.

Kelber, A., Warrant, E.J., Pfaff, M., Wallén, R., Theobald, J.C., Wcislo, W.T., Raguso, R.A., 2006. Light intensity limits foraging activity in nocturnal and crepuscular bees. Behavioral Ecology 17, 63-72.

Kirk, W.D.J., Howes, F.N., 2012. Plants for Bees: A Guide to the Plants That Benefit the Bees of the British Isles. International Bee Research Association. 
Version définitive du manuscrit publiée dans / Final version of the manuscript published in :

Agriculture, Ecosystems and Environment (2013), Vol. 179, p. 78-86, DOI: 10.1.016/j.agee.2013.07.007

\section{Journal homepage: www.elsevier.com/locate/agee}

Kleijn, D., Berendse, F., Smit, R., Gilissen, N., 2001. Agri-environment schemes do not effectively protect biodiversity in Dutch agricultural landscapes. Nature 413, 723-725.

Kleijn, D., Sutherland, W.J., 2003. How effective are European agri-environment schemes in conserving and promoting biodiversity? Journal of Applied Ecology 40, 947-969.

Klein, A.-M., Vaissiere, B.E., Cane, J.H., Steffan-Dewenter, I., Cunningham, S.A., Kremen, C., Tscharntke, T., 2007. Importance of pollinators in changing landscapes for world crops. Proceedings of the Royal Society B: Biological Sciences 274, 303-331.

Knop, E., Kleijn, D., Herzog, F., Schmid, B., 2006. Effectiveness of the Swiss agrienvironment scheme in promoting biodiversity. Journal of Applied Ecology 43, $120-127$.

Kwon, Y.J., Saeed, S., 2003. Effect of temperature on the foraging activity of Bombus terrestris L. (Hymenoptera: Apidae) on greenhouse hot pepper (Capsicum annuum L.). Applied Entomology and Zoology 38, 275-280.

Michener, C.D., 2007. The Bees of the World, 2nd Revised Edition. Johns Hopkins University Press.

Odoux, J.-F., Feuillet, D., Aupinel, P., Loublier, Y., Tasei, J.-N., Mateescu, C., 2012. Territorial biodiversity and consequences on physico-chemical characteristics of pollen collected by honey bee colonies. Apidologie 44, 561-575.

Ollerton, J., Winfree, R., Tarrant, S., 2011. How many flowering plants are pollinated by animals? Oikos 120, 321-326.

Potts, S., Roberts, S., Dean, R., Marris, G., Brown, M., Jones, R., Neumann, P., Settele, J., 2010. Declines of managed honey bees and beekeepers in Europe. Journal of Apicultural Research 49, 15.

Potts, S.G., Vulliamy, B., Dafni, A., Ne'eman, G., Willmer, P., 2003. Linking bees and flowers: how do floral communities structure pollinator communities? Ecology 84, 2628-2642.

R Development Core Team, 2010. R: A Language and Environment for Statistical Computing. R Foundation for Statistical Computing, Vienna, Austria, ISBN:3900051-07-0.

Ranta, E., Lundberg, H., 1980. Resource partitioning in bumblebees: the significance of differences in proboscis length. Oikos 35, 298-302.

Rhodes, J.R., McAlpine, C.A., Zuur, A.F., Smith, G.M., Ieno, E.N., 2009. GLMM applied on the spatial distribution of Koalas in a fragmented landscape. In: Mixed Effects Models and Extensions in Ecology with R, Statistics for Biology and Health. Springer, New York, pp. 469-492.
Ricketts, T.H., Regetz, J., Steffan-Dewenter, I., Cunningham, S.A., Kremen, C., Bogdanski, A., Gemmill-Herren, B., Greenleaf, S.S., Klein, A.M., Mayfield, M.M., Morandin, L.A., Ochieng', A., Viana, B.F., 2008. Landscape effects on crop pollination services: are there general patterns? Ecology Letters 11, 499-515.

Saveliev, A.A., Cronin, M., Zuur, A.F., Ieno, E.N., Walker, N.J., Smith, G.M., 2009. Incorporating temporal correlation in seal abundance data with MCMC. In: Mixed Effects Models and Extensions in Ecology with R, Statistics for Biology and Health. Springer, New York, pp. 503-529.

Steffan-Dewenter, I., Kuhn, A., 2003. Honeybee foraging in differentially structured landscapes. Proceedings of the Royal Society of London Series B: Biological Sciences 270, 569-657.

Steffan-Dewenter, I., Tscharntke, T., 2001. Succession of bee communities on fallows. Ecography 24, 83-93.

Tscharntke, T., Klein, A.M., Kruess, A., Steffan-Dewenter, I., Thies, C., 2005. Landscape perspectives on agricultural intensification and biodiversity - ecosystem service management. Ecology Letters 8, 857-874.

Tscharntke, T., Tylianakis, J.M., Rand, T.A., Didham, R.K., Fahrig, L., Batáry, P., Bengtsson, J., Clough, Y., Crist, T.O., Dormann, C.F., Ewers, R.M., Fründ, J., Holt, R.D. Holzschuh, A., Klein, A.M., Kleijn, D., Kremen, C., Landis, D.A., Laurance, W. Lindenmayer, D., Scherber, C., Sodhi, N., Steffan-Dewenter, I., Thies, C., Van der Putten, W.H., Westphal, C., 2012. Landscape moderation of biodiversity patterns and processes - eight hypotheses. Biological Reviews 87, 661-685.

VanEngelsdorp, D., Hayes, J., Underwood, R.M., Pettis, J., 2008. A survey of honey bee colony losses in the U.S., fall 2007 to spring 2008. PLoS ONE 3, e4071.

Velthuis, H.H.W, van Doorn, A, 2006. A century of advances in bumblebee domestication and the economic and environmental aspects of its commercialization for pollination. Apidologie 37, 31 .

Westphal, C., Bommarco, R., Carré, G., Lamborn, E., Morison, N., Petanidou, T., Potts, S.G., Roberts, S.P.M., Szentgyörgyi, H., Tscheulin, T., Vaissière, B.E., Woyciechowski, M., Biesmeijer, J.C., Kunin, W.E., Settele, J., Steffan-Dewenter, I., 2008 Measuring bee diversity in different european habitats and biogeographica regions. Ecological Monographs 78, 653-671.

Westphal, C., Steffan-Dewenter, I., Tscharntke, T., 2009. Mass flowering oilseed rape improves early colony growth but not sexual reproduction of bumblebees. Journal of Applied Ecology 46, 187-193.

Zuur, A.F., Ieno, E.N., Walker, N.J., Saveliev, A.A., Smith, G.M., 2009. Mixed effects modelling for nested data. In: Mixed Effects Models and Extensions in Ecology with R, Statistics for Biology and Health. Springer, New York, pp. 101-142. 